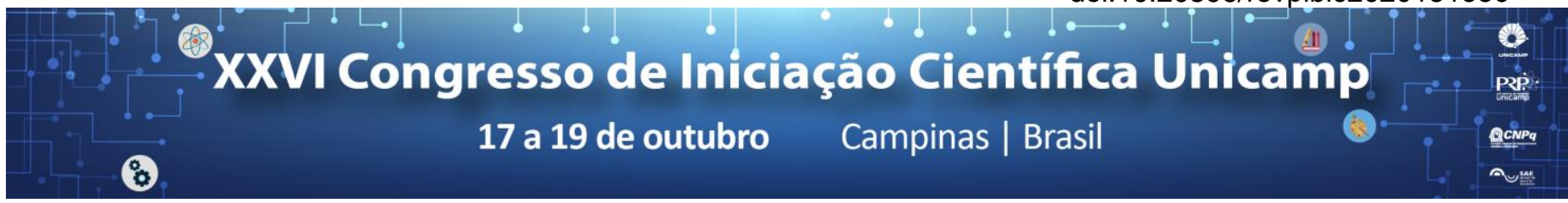

\title{
O uso e a preservação digital das bases de dados do Centro de Pesquisa em História Social da Cultura do Instituto de Filosofia e Ciências Humanas da Unicamp
}

\author{
Autor: Willian de Carvalho Silva \\ Orientador: Prof. Dr. Aldair Carlos Rodrigues
}

\begin{abstract}
Resumo
A criação e o uso de bases de dados digitais na pesquisa histórica têm facilitado o acesso e ampliado as ações sobre as fontes documentais. No entanto, importantes questões podem ser levantadas quando pensamos nos desafios da preservação de documentos arquivísticos digitais, estáticos e dinâmicos, produzidos a partir de sistemas informatizados e banco de dados. Na tentativa de entender alguns desses desafios, esse trabalho analisa duas das principais bases de dados do Centro de Pesquisa em História Social da Cultura do Instituto de Filosofia e Ciências Humanas da Unicamp buscando desenvolver um plano de preservação arquivístico digital.
\end{abstract}

Palavras-chave: preservação digital, bases de dados, história.

\section{Introdução}

O Centro de Pesquisa em História Social da Cultura (Cecult) do Instituto de Filosofia e Ciências Humanas da Unicamp se destaca como um importante exemplo do uso de base de dados digitais para a pesquisa histórica. Nesse sentido, o uso dessas ferramentas digitais têm trazido importantes questões em relação a preservação de documentos arquivísticos digitais, já que a necessidade de se pensar em fatores como a rápida obsolescência tecnológica, a fragilidade do armazenamento digital e a dependência social da informação digital se faze cada vez mais presente. Portanto, esse estudo tem por objetivo uma análise descritiva e diagnóstica das bases de dados digitais "Legislação: Trabalhadores e Trabalho em Portugal, Brasil e África Colonial Portuguesa" e "Dissídios: Trabalhadores e Justiça do Trabalho" que contribuíram em um plano estratégico de preservação arquivístico digital para essas mesmas bases. Além disso, buscamos refletir sobre as atuais demandas e competências atribuídas ao historiador contemporâneo diante da criação e apropriações de novas tecnologias pelo campo da História.

\section{Resultados e Discussão}

Preliminarmente, foi constatado a ausência de um plano estratégico a longo prazo que visasse a preservação das bases de dados do centro de pesquisa em questão. No entanto, medidas de segurança como backups e redundância dos servidores foram identificadas.

Foram obtidas ainda as seguintes informações sobre as bases de dados selecionadas: sistema operacional Linux com gerenciamento de aplicação Web Apach; sistema gerenciador de banco de dados objeto relacional Postgresql; linguagem de programação Hypertext Preprocessor (PHP) e framework de desenvolvimento Symfony.

Essas informações refletem o uso de softwares livres e reconhecidos, sendo uma importante condição para o plano estratégico de preservação digital traçado. Entre essa e outras condições alguns requisitos, assim como proposto no modelo conceitual de preservação digital de Inarelli (INARELLI, p.276), devem ser seguidos para garantir a manifestação e a contextualização do documento arquivístico digital. São eles: forma fixa, conteúdo estável, independência de sistema informatizado, variabilidade limitada, autenticidade e cópias de segurança.

Figura 1. Manifestação do documento arquivístico digital por sistema informatizado e SGBD.

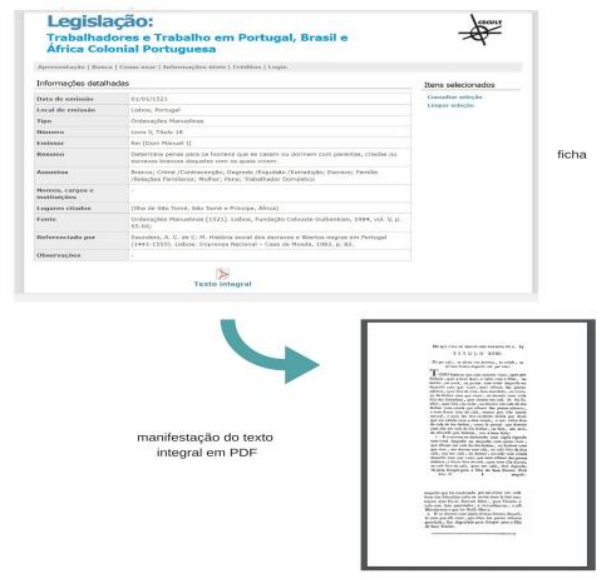

\section{Conclusões}

Concluímos que esses resultados contribuíram com reflexões sobre o uso de bases de dados em pesquisas históricas e serviram na formulação de um plano estratégico de preservação digital para o Centro de Pesquisa em História Social da Cultura. Sendo assim, essa pesquisa também tentou trazer novas questões que ampliassem as discussões sobre a história digital e demonstrou a importância dos debates em torno das novas ferramentas digitais para o ofício do historiador contemporâneo.

INNARELLI, Humberto Celeste. Gestão da preservação de documentos arquivísticos digitais: proposta de um modelo conceitual. São Paulo: H. C. Innarelli, 2015.

SAMARA, Eni de Mesquita; TUPY, Ismênia. História \& Documentos e metodologia de pesquisa. Belo Horizonte: Autêntica, 2007. 